\title{
3. Advocacy as core business: new philanthropy strategies in Brazilian education policy-making
}

\section{Marina Avelar}

Influential foundations and institutes increasingly describe "advocacy" as a crucial part of their activity and often mention it as a distinctive trait of their work in contrast to former ways of "giving." This chapter aims to analyse the strategies new philanthropy is adopting to advance its agenda in education policy-making in Brazil, or how it "does advocacy." This new philanthropy advocacy is taking place in the context of a changing role of the state, which is moving from a hierarchical government to networks of governance (Rhodes, 1996). Concomitantly, philanthropy is also changing by embracing corporate practices and discourses, referred to as the "new philanthropy"1 (Ball and Junemann, 2012), which "treats donations as investments, results as returns, and wants to be involved in decisions about how money is used" (Avelar and Ball, 2017: n.p.).

To better understand how these philanthropic organisations have been operating and gaining space and leverage in the education policy-making arena, this chapter analyses some "advocacy" practices, or strategies, using "network ethnography" (Howard, 2002). The method entails extensive and exhaustive online searches, interviews, and observation of events. Data was collected through Internet searches, analysing institutional websites, CVs, reports and

1 In spite of its increasing relevance, this new philanthropy shift is not a definitive or homogeneous change in the sector, nor does it refer to a specific group of foundations. 
pieces of news, and fieldwork was conducted in 2016. Throughout data collection and analysis, policy network graphs are built as a tool to identify relevant individuals, institutions, relationships and activities associated with specific policies or networks. The analysed practices that follow are from new philanthropy organisations identified as central (highly connected and influential) in Brazil, namely Todos pela Educação (TPE), Lemann Foundation, Natura Institute, Ayrton Senna Institute and Unibanco Institute.

The chapter first discusses the relation between new philanthropy and education policy-making. Second, it introduces four main strategies new philanthropy has been developing in Brazil around education policy. Finally, it discusses how these practices together have been creating conditions for an effective participation in education policy-making in the country, allowing the advancement of a range of common aims. I argue that to understand new philanthropy's work in education policy-making we must see its activity not as "outsiders" aiming to convince state policymakers, but rather as active members of a network of governance, or the heterarchical state.

\section{NEW PHILANTHROPY AND EDUCATION POLICY-MAKING}

Some research has been done around the work of new philanthropy in education policy advocacy, demonstrating a consistent global growth in philanthropy's participation in education policy-making. In the USA specially, some authors have been investigating the topic. The growth of advocacy was clearly illustrated with the study of Reckhow and Snyder (2014), who investigated giving patterns among the 15 largest education foundations in the country and demonstrated a growing financial support for national-level advocacy organisations. Ferrare and Reynolds (2016) conducted a similar study to analyse smaller foundations and their pattern of social investment. The trend towards investment in advocacy was also identified. Both studies gathered data about foundation donations through the Form 990 tax documents, published online by the Foundation Center.

With a different approach, some authors have also studied the philanthropic involvement in education policy in England (Ball and 
Junemann, 2012; Ball, 2012; Olmedo, 2014, 2017), as well as related global networks, which extend to sub-Saharan Africa and India (Ball, Junemann and Santori, 2017). These studies discuss how new philanthropy composes networks that assemble an "'epistemic community' organised around specific interpretations of existing social problems, emerging business niches, and new policy solutions" (Santori, Ball and Junemann, 2015: 24). In this sense, the authors examine more opaque ways in which new philanthropy participates in policy-making, playing fundamental discursive and relational roles.

A growing presence of new philanthropy in education policymaking has also been identified and analysed in Latin America. Peroni and Adrião $(2006,2008)$ have analysed how foundations in Brazil have been promoting an agenda referred to as the Global Education Reform Movement (GERM) (Sahlberg, 2011), fomenting the privatisation of education services and the standardisation of teaching in public schools. Similarly, other authors have studied specific foundations and discussed how they have been successful in disseminating market-based policies in Brazilian education, including some organisations considered in this chapter such as TPE (Martins and Krawczyk, 2016; Martins, 2016), Ayrton Senna Institute (Comerlatto and Caetano, 2013), and Unibanco Institute (Monteiro, 2013). New philanthropy has been a powerful actor in education policy-making as connecting nodes between non-profit, for-profit and state institutions.

Thus, partaking in policy-making, or doing what new philanthropists often refer to as "advocacy," is becoming not only part of philanthropy's activities, but indeed a crucial goal. In Brazil, a fundamental difference between peripheral and central philanthropies is the aim of influencing policy. Smaller organisations, which are placed on more peripheral positions in the network, conduct local work, with local authorities and other small NGOs. Larger and central foundations, on the other hand, describe policy-making as a fundamental aspect of their work. As David Saad, the Executive Secretary of the Natura Institute, asserts: "in practically all we do we have a desire that it may become a public policy" (Interview Natura Institute, 2016). Policy is both means and ends for these institutions: they aim to influence it, and use it as a way to reach the desired high-scale changes in education. 
This trend is confirmed by the 2015 biannual survey conducted by the Group of Corporate Foundations and Institutes (GIFE in Portuguese), which connects Brazilian corporations and corporate, independent, family, and community associations and foundations that do "social investments for public benefit in Brazil" (GIFE's website). Amongst GIFE's members, 85 per cent indicate education as its priority investment. With a hands-on approach, 37 per cent run their own programs, 45 per cent run and fund projects and only 18 per cent of respondents primarily fund other civil society organisations. Regarding the involvement with policy, 89 per cent of respondents claim their work is related to public policy, and 58 per cent declare to aim at directly influencing or supporting policy-making. Moreover, amongst the ones that invest more than US\$21 million, 75 per cent aim at influencing policy. Thus, there is a growing social investment from philanthropy in Brazil, which is mainly focused on education and aims at influencing policy.

\section{NEW PHILANTHROPY STRATEGIES IN EDUCATION POLICY-MAKING IN BRAZIL}

Within this growing relevance of new philanthropy and its focus on education policy, below is an analysis of four fundamental "advocacy" practices these organisations have been adopting to participate in education policy-making in Brazil.

\section{Creating a Basis for Action: 'Studies' and Reports}

To perform advocacy, first, foundations fund and conduct studies to create the discursive basis and justifications for their positions, proposals and activities. These studies are fundamental for the other advocacy efforts, and there has been a growth in this type of work in Brazil since 2013. Before 2013 few reports had been produced, but since then most central foundations have been investing in the production of "research."

These studies come in an array of formats and sizes, including small exploratory efforts to large-scale and heavily-funded studies, produced by known scholars in universities. In the first case, studies can be executed as a preliminary stage within a project, like Instituto Natura did with a project called "Full-time Schools." A 
representative from this institute affirmed that conducting an exploratory research is a "necessary first stage of a project" (Interview Natura Institute, 2016). On the other hand, studies can be more ambitious, emanating from an internal "research" department in foundations, or as part of a funding area, when studies are contracted out. Ayrton Senna Institute has mostly carried out its own studies, usually in partnership with another institution. Differently, Lemann Foundation, Natura Institute, Unibanco Institute and TPE have contracted out for reports from research organisations. Further, searching for legitimacy, some foundations have been developing close relationships to universities, including Lemann Foundation and Ayrton Senna Institute. The first has partnerships with Columbia University, Harvard University, Stanford University, University of Illinois, UCLA, Yale University and the University of Oxford; and the second with Insper, in Brazil, and the University of Ghent, in Belgium. Also participating in research spaces, including academic ones, TPE has been presenting papers in conferences and seminars, publishing papers in journals and conference proceedings, and partaking in different studies, including policy analysis for the government.

These studies are based on pre-existing epistemic positions of foundations. Foundations hire staff, consultants, or research organisations that hold similar epistemic and political positions as them. This practice produces what Hogan, Sellar and Lingard (2015) call a "new policy genre," that "over-simplifies complicated policy issues and, moreover, sets a new standard for accessible "policyrelevant' data analysis that prioritises impact over rigour" (Hogan, Sellar and Lingard, 2015: 52). An interviewee from the Lemann Foundation describes how it has been working for the advocacy of a new standard curriculum in Brazil with the Movement for the National Common Base (MNCB): "we started producing research here in Brazil about the need of having a common curricular base to Brazilian students ... This is what we try to do, the focus of our advocacy is making sure that people can make decisions based on evidence, having subsidies to make the best choices. So this is what we do, we share information." With a clear agenda, studies are carried to "demonstrate the need" of a particular policy solution, which is introduced as "evidence" (Interview Lemann Foundation, 2016). 
In this sense, new philanthropists have been operating as "policy entrepreneurs" (Kingdon, 1984), as individuals or groups that participate in policy-making through two main activities: defending ideas and fostering policy change (Capella, 2016). Carrying out studies is fundamental to legitimising such ideas and framing them in ways that can be regarded as "evidence-based," although the policy objective often precedes the production of the supporting evidence. Defending the underlying ideas involves disseminating them to both policymakers and the general public, which often involves the press, as explored below.

\section{Working with the Press: The Creation of the Specialist}

New philanthropists have a growing presence in the press as columnists in newspapers and magazines or invited commentators on broadcast media on policy issues. They are increasingly gaining the status of "specialists," occupying a central role in public debates about education. From TPE, Priscila Cruz is the writer of a weekly column in UOL Educação, from the large newspaper Folha. Viviane Senna (Ayrton Senna Institute) and Ricardo Henriques (Unibanco Institute) are often interviewed in major newspapers to discuss education policy issues. Similarly, the studies and reports explored in the previous session are often disseminated in the press as well.

Foundations may even account for "media hits" in their annual reports as part of their "impact." TPE proudly reported 12 published articles in press, 2000 press clippings, 600 interview requests and 100 journalists trained on "how to cover education in the press" in 2015. Similarly, Unibanco Institute reported 609 mentions in press, with 131 in the national press and 189 specifically mentioning Ricardo Henriques, the institute's Executive Superintendent. Arguably, this is beneficial for these organisations not only for the construction of the "specialist" image, but also for marketing purposes within the logics of philanthrocapitalism (Bishop and Green, 2010; McAlister and Ferrell, 2002). Except for TPE, the other four institutes carry with them the names of the funding companies or businessman.

Working with the press is central to the policy entrepreneur. Policy entrepreneurs need public legitimacy, which usually emanates from their expertise, their communication skills or their position in the formal process of decision (Kingdon, 1984). By 
working with the press, new philanthropy is able to draw on its studies and public communication to build up an image of competence, in spite of being outside official decision-making processes or traditional locations of "expertise" in teaching and learning institutions. Relatedly, the press can be used to create pressure on governments, which is made clear by a Lemann Foundation representative in saying: "with the press as well, in a last case, if we truly believe in a cause and the Ministry of Education and the government do not abide by it, then going to the press is always a good opportunity" (Interview Lemann Foundation, 2016).

Yet another relationship built between foundations and the press in Brazil concerns the ownership of communication vehicles. For example, the Lemann Foundation and the Ayrton Senna Institute are owners of education magazines. The Lemann Foundation has purchased two "non-profit" magazines in education: Nova Escola and Gestão Escolar. These are the two largest magazines for teachers and educators in the country, with more than 120,000 magazines sold per volume, 45,000 subscribers and 2.5 million website visits per month. Besides being a large vehicle of communication, influence and discourse sharing with teachers and head teachers, these magazines are also a space for the commodification of education. In spite of being "non-profit," companies can purchase advertisement space in the magazine, including the so-called "branded content" whereby "practical and informative content" (Nova Escola website), is offered with the name of the sponsor prominently displayed. Here, the selling of education products and services can be masked as "practical" and "informative" content, and as technical support for teachers.

\section{"Meetingness": Events as Places for Networking and Advocacy}

Also used as spaces for framing and sharing policy ideas, meetings and events are strategically promoted by foundations and are a fundamental part of how they operate. These are spaces attentively crafted for policy-making that involve carefully selected values, speakers and attendees. Meetings are central to networks, and are "necessary to 'form' and to 'cement' weak ties at least for another stretch of time" (Urry, 2007: 231). By "meetings" Urry (2007) refers to "both the highly formalized with 'agendas,' structure and timetables and the informal to where the specific space and time are 
planned in advance to where they are negotiated en route" (Urry, 2007: 232). In such spaces "network members from a range of backgrounds, come together, where stories are told, visions shared, arguments reiterated, new relations made, partnerships forged, and commitments made" (Ball, 2017: 35), all of which construct "meetingness" (Urry, 2007). There is both a discursive aspect in meetings, through the fostering of policy ideas, and a relational one, with the creation and strengthening of social relationships. Thus, the practice of "meetingness" combines both the policy entrepreneurship of defending ideas and the encouragement of policy change.

Concerning the discursive aspect, a representative from Lemann Foundation describes events as the following: "It is about working in the same way as in advocacy, we bring subsidies for the discussion, we promote exchanges, meetings, talking ..." (Interview Lemann Foundation, 2016). Hence, seminars often present the results of the studies mentioned earlier and are planned to gather the "right" people. They bring together the selected "specialists," who will articulate and reinforce the funder's beliefs, with "everyone that is important in this debate" (Interview, Lemann Foundation), or the policymakers and supporters needed to advance their agenda. In these spaces, discourses are shared, policy solutions are presented and public-private partnerships are created or maintained.

Regarding the relational aspect, promoting events reinforces weak relationships that are fundamental for the maintenance of a network of governance. These events provide opportunities for "talk and touch," fostering trust in a policy network (Junemann, Ball and Santori, 2015). Representatives from the different institutions attend each other's events, thus maintaining relationships and discourses. Except for Natura Institute, the other four analysed institutions have their own seminar series, which usually include an annual or biannual meeting that gathers representatives from government, new philanthropy, business and research. For example, Lemann Foundation organises an annual conference with Stanford, in which all Lemann Fellows (research students funded by Lemann Foundation) present the results of their studies to an audience with representatives from diverse organisations. Another example is the seminar organised by the Unibanco Institute in 2015, which gathered many representatives of the advocacy group "Mobilisation for the National Learning Standards" and the Ministry of Education in 
a pivotal moment of debate about the creation of a standard learning standards in Brazil (Avelar, Nikita and Ball, 2018).

\section{Networking: Building Coalitions and Working with the State}

The three previous strategies could be understood as being somewhat employed by each foundation individually, defending its own policy ideas. However, the last practice shifts the perspective under which we understand how new philanthropy works around policymaking. Foundations work embedded in networks, with partnerships that may be limited to specific projects or constant institutional collaborations. Money, institutional resources, expertise and social capital are all shared through collaborative partnerships (Ball and Junemann, 2012).

Concerning advocacy, working with other foundations is profoundly beneficial, as Denis Mizne, the Executive Secretariat of Lemann Foundation, stated in a speech, "having a coalition with other institutions gives us greater impact." TPE is an illustrative example of an advocacy coalition highly active in education policymaking in Brazil (Martins, 2016). TPE brings together corporate, philanthropic and state representatives and makes use of all the previously mentioned strategies: it produces research, counts with a powerful communications strategy, organises and participates in many events and assembles a vast network (Martins and Krawczyk, 2016).

However, networks do not concern only private-private relationships. Through networks new philanthropy participates actively in the public governance of education. Public-private partnerships (PPP) are a well-known format in which this participation in governance can take place (Robertson, Mundy and Verger, 2012). For example, the project "Devolutivas pedagógicas" (Pedagogical Feedback) is a platform created by the Ministry of Education to offer support to schools to interpret their results in large-scale exams. The platform, however, was created by two public organisations (MEC and INEP), together with two foundations (TPE and Unibanco Institute).

Besides PPPs, there are other spaces where new philanthropy participates in networks of governance, which are often more opaque and unaccountable to citizens (Santori, Ball and Junemann, 2015). The "Mobilisation for the National Learning Standards" 
(MNLS) is an example. This group of people and organisations, that defines itself as an "advocacy movement," is led by Lemann Foundation and is supported by 11 foundations (including all five foundations considered in this chapter) together with almost 100 people. With a co-affiliation network analysis of the individual members, one can see that more than half of MNLS's supporters work as public servants in education, including in the Ministry of Education and the National Council of Education, the highest federal spaces of education policy. Thus, not only has this movement been providing different services to the Ministry of Education, such as producing reports for the government and conducting seminars for discussing the new curriculum, but more importantly, some of the MNLS's members, who participate in its private meetings, are directly involved or responsible for the curriculum policy in the government. MNLS then assembles a new space for policy-making, in which philanthropy and state discusses education policy without a formal PPP or public instruments of accountability (see Avelar and Ball, 2017).

\section{FINAL REMARKS: GOING BEYOND "ADVOCACY" AND PARTAKING IN HETERARCHICAL GOVERNANCE}

Large new philanthropy organisations in Brazil increasingly claim their main purpose is to influence education policy. To understand this "advocacy" work, practices can be analysed to elucidate how foundations are operating. Here I focused on four practices producing research, working with the press, promoting events and operating in networks - that show there has been intense work around policy-making by new philanthropy. These strategies are not necessarily new in policy-making. What may be regarded as a novelty is that private organisations are using such strategies to participate in policy-making in the field of education. This is taking place amid wider shifts from government to governance and the concomitant reworking of the state, the market and philanthropy, in which "philanthropies of various kinds are taking on the moral responsibilities of the state articulated within a complex global 
architecture of economic and social relations" (Avelar and Ball, 2017: n.p.).

In this sense, out of the analysed strategies I highlight networks as a fundamental trait that allows us to see new philanthropy in a new perspective: not so much as "outsider advocates," but more as "heterarchy members," here understood as:

Heterarchy is an organisational form somewhere between hierarchy and network that draws upon diverse horizontal and vertical links that permit different elements of the policy process to cooperate (and/or compete). Heterarchies have many of the characteristics of "assemblages" of and for policy and governance, inasmuch as they contain heterogeneous elements placed in diverse relations to one another, in latent structures or as social morphology. (Ball and Junemann, 2012: 138)

New philanthropy efforts in participating in education policymaking now go beyond what is traditionally understood as "advocacy." Often, their labour is not executed as an advocacy from "outside," where one tries to influence policymakers "inside" public spaces of decision-making. Instead, the participation of new philanthropy in policy-making is better understood when conceived as collaboration with policymakers within heterarchies. In this sense, the first three practices analysed here (producing research, working with the press and promoting events) position new philanthropy as "policy entrepreneurs," granting new philanthropy the status of "specialists" and enabling the creation and maintenance of invaluable relationships. Such practices, within the broader context of neoliberal shifts towards network governance, allow new philanthropy to operate not as a policy influencer, but indeed, as part of the policy-making process itself.

In spite of being non-profit, the work of new philanthropy in education policy furthers the blurring between public and private, and between non-profit and for-profit. Influential foundations are frequently funded by large companies and wealthy businessman, have partnerships with for-profit organisations and companies, and support GERM policies, often related to the privatisation of education services. Hence, new philanthropy can alarmingly support the development of a global education industry, which fosters "the idea of education for investment and profit making" (Verger, 
Lubienski, and Steiner-Khamsi, 2016: 1) and may lead to democratic deficits in education.

\section{REFERENCES}

Avelar, M. and Ball, S.J. (2017). Mapping new philanthropy and the heterarchical state: the Movement for the National Common Base in Brazil. International Journal of Educational Development. In press.

Avelar, M., Nikita, D.P. and Ball, S.J. (2018). Education policy networks and spaces of "meetingness": a network ethnography of a Brazilian seminar. In Verger, A., Altinyelken, H.K. and Novelli, M. (eds) Global Education Policy and International Development (2nd edn). London: Bloomsbury Publishing, $56-74$.

Ball, S.J. (2012). Global Education Inc: New Policy Networks and the Neo-Liberal Imaginary. London: Routledge.

Ball, S.J. (2016). Following policy: networks, network ethnography and education policy mobilities. Journal of Education Policy, 31(5), 549-566.

Ball, S.J. (2017). Laboring to relate: neoliberalism, embodied policy, and network dynamics. Peabody Journal of Education, 92(1), 29-41.

Ball, S.J. and Junemann, C. (2012). Networks, New Governance and Education. London: Policy Press.

Ball, S.J., Junemann, C. and Santori, D. (2017). Edu.Net: Globalisation and Education Policy Mobility. London: Taylor \& Francis.

Bishop, M. and Green, M. (2010). Philanthrocapitalism: How Giving Can Save the World. New York: Bloomsbury Publishing.

Capella, A.C.N. (2016). A study on the concept of public policy entrepreneur: ideas, interests, and changes. Cadernos EBAPE.BR, 14(SPE), 486-505.

Comerlatto, L. and Caetano, R. (2013). As parcerias público-privadas na educação brasileira e as decorrências na gestão da educação: o caso do IAS. Relações entre o público e o privado e implicações para a democratização da educação: diálogos entre Brasil, Argentina, Portugal e Inglaterra. Brasília: Editora Líber.

Ferrare, J.J. and Reynolds, K. (2016). Has the elite foundation agenda spread beyond the gates? An organizational network analysis of nonmajor philanthropic giving in K-12 education. American Journal of Education, 123(1), 137-169.

Hogan, A., Sellar, S. and Lingard, B. (2015). Network restructuring of global edu-business: The case of Pearson's Efficacy Framework. In Au, W., Ferrare, J.J. (eds) Mapping Corporate Education Reform: Power and Policy Networks in the Neoliberal State. New York: Routledge, 43-63.

Howard, P.N. (2002). Network Ethnography and the hypermedia organization: New media, new organizations, new methods. New Media \& Society, 4(4), $550-574$.

Junemann, C., Ball, S.J. and Santori, D. (2015). Joined-up policy. In Mundy, K., Green, A., Lingard, B. and Verger, A. (eds) The Handbook of Global Education Policy. New Jersey: Wiley, 535-553. 
Kingdon, J.W. (1984). Agendas, Alternatives, and Public Policies (Vol. 45). New York: Little, Brown Boston.

Martins, E.M. (2016). Todos pela Educação? Como os empresários estão determinando a política educacional brasileira. Rio de Janeiro: Lamparina.

Martins, E.M. and Krawczyk, N.R. (2016). Entrepreneurial influence in Brazilian education policies. In Verger, A., Lubienski, C., Steiner-Khamsi, G. (eds) World Yearbook of Education 2016: The Global Education Industry, New York: Routledge, 78-89.

McAlister, D. and Ferrell, L. (2002). The role of strategic philanthropy in marketing strategy. European Journal of Marketing, 36(5/6), 689-705.

Monteiro, M. (2013). Relação Público-Privada na Educação Básica no Brasil: uma Análise da Proposta do Instituto Unibanco para o Ensino Médio Público. Redefinições Das Fronteiras Entre O Público E O Privado: Implicações Para a Democratização Da Educação. Brasília: Liber Livro.

Olmedo, A. (2014). From England with love ... ARK, heterarchies and global "philanthropic governance". Journal of Education Policy, 29(5), 575-597.

Olmedo, A. (2017). Something old, not much new, and a lot borrowed: philanthropy, business, and the changing roles of government in global education policy networks. Oxford Review of Education, 43(1), 69-87.Peroni, V.M.V. and Adrião, T. (2006). Mudanças na configuração do Estado e sua influência na política educacional. Dilemas Da Educação Brasileira Em Tempos de Globalização Neoliberal: Entre O Público E O Privado. Porto Alegre: Editora Da UFRGS, 11-23.

Peroni, V.M. and Adrião, T. (2008). A relação público/privado e a gestão da educação em tempos de redefinição do papel do Estado. Público E Privado Na Educação: Novos Elementos Para O Debate. São Paulo, SP: Xamã, 111-127.

Reckhow, S. and Snyder, J.W. (2014). The expanding role of philanthropy in education politics. Educational Researcher, 43(4) 186-195.

Rhodes, R.A.W. (1996). The new governance: governing without government. Political Studies, 44(4), 652-667.

Robertson, S., Mundy, K. and Verger, A. (eds) (2012). Public Private Partnerships In Education: New Actors And Modes Of Governance In A Globalizing World. Cheltenham, UK and Northampton, MA, USA: Edward Elgar Publishing.

Sahlberg, P. (2011). The fourth way of Finland. Journal of Educational Change, 12(2), 173-185.

Santori, D., Ball, S.J. and Junemann, C. (2015). mEducation as a site of network governance. In Au, W., Ferrare, J.J. (eds) Mapping Corporate Education Reform: Power and Policy Networks in the Neoliberal State. New York: Routledge, 23-42.

Urry, J. (2007). Mobilities. Cambridge: Polity Press.

Verger, A., Lubienski, C. and Steiner-Khamsi, G. (2016). World Yearbook of Education 2016: The Global Education Industry. London: Routledge. 